\title{
B-mode and Doppler ultrasonography of abdominal structures of the peccary (Tayassu tajacu, Linnaeus 1758)
}

[Ultrassonografias Doppler e modo-B das estruturas abdominais de catetos (Tayassu tajacu Linnaeus, 1758)]

\author{
G.T. Pessoa ${ }^{1}$, F.C.A. Sousa ${ }^{2}$, R.P.S. Rodrigues ${ }^{1}$, L.S. Moura ${ }^{1}$, E.G. Silva ${ }^{1}$, \\ A.N. Diniz ${ }^{3}$, A.B. Souza ${ }^{1}$, M.A.P.S. Barbosa ${ }^{1}$, J.R. Araújo ${ }^{1}$, A.B.S. Silva ${ }^{1}$, \\ J.J.R.P. Alves ${ }^{4}$, F.R. Alves ${ }^{1 *}$
}

${ }^{1}$ Universidade Federal do Piauí - Teresina, PI

${ }^{2}$ Universidade Estadual do Piauí - Teresina, PI

${ }^{3}$ Universidade Federal de Alagoas - Viçosa, AL

${ }^{4}$ Hospital Universitário - Universidade Federal do Piauí - Teresina, PI

\begin{abstract}
This study used B-mode and Doppler ultrasonography to characterize the abdominal structures of healthy peccaries raised in captivity. Fifteen peccaries were used for this study. The urinary vesicle appeared as an ovoid structure, located in the abdominal and pelvic transition, with a hyperechogenic, thin, smooth, and regular wall. The kidneys presented retroperitoneal topography and had similar sizes. The kidney/aorta ratio had an average value of $10.53 \pm 15 \mathrm{~cm}$ (right) and $10.23 \pm 0.12$ (left). The right adrenal gland had a length of $1.93 \pm 0.34 \mathrm{~cm}$ and diameter of $0.56 \pm 0.16 \mathrm{~cm}$. The left adrenal gland had a length of $1.85 \pm 0.42 \mathrm{~cm}$ and diameter of $0.52 \pm 0.11 \mathrm{~cm}$. The spleen had a diameter of $1.13 \pm 0.18 \mathrm{~cm}$. The hepatic vein demonstrated polyphasic flow in pulsed Doppler, with two retrograde peaks and an anterograde peak with a flow velocity of $25.7 \pm 0.83 \mathrm{~cm} / \mathrm{s}$. The abdominal aorta had a diameter of $0.58 \pm 0.05 \mathrm{~cm}$ and a flow velocity of $115.17 \pm 5.32 \mathrm{~cm} / \mathrm{s}$. The morphological and hemodynamic study of the abdominal structures of the peccary, observed through B-mode and Doppler ultrasonography, aided in identifying the size, shape, position, echogenicity, and echotexture of the abdominal organs and in making inferences about the normal parameters for these structures in this species.
\end{abstract}

Keywords: abdomen, hemodynamics, morphology, tayassuidae, ultrasound

\section{RESUMO}

Este estudo teve como objetivo utilizar as ultrassonografias de modo-B e Doppler para caracterizar as estruturas abdominais de um cateto sadio criado em cativeiro. Quinze catetos foram utilizados para este estudo. A vesícula urinária apareceu como uma estrutura ovoide, localizada na transição entre as partes abdominal e pélvica, com uma parede hiperecogênica, fina, lisa e regular. Os rins apresentaram topografia retroperitoneal e tamanhos semelhantes. A relação rim/aorta teve um valor médio de $10,53 \pm 15 \mathrm{~cm}$ (direita) $e$ $10,23 \pm 0,12 \mathrm{~cm}$ (esquerda). A glândula adrenal direita tinha um comprimento de $1,93 \pm 0,34 \mathrm{~cm}$ e um diâmetro de 0,56 $\pm 0,16 \mathrm{~cm}$. A glândula suprarrenal esquerda tinha um comprimento de 1,85 $\pm 0,42 \mathrm{~cm}$ e um diâmetro de $0,52 \pm 0,11 \mathrm{~cm}$. O baço tinha um diâmetro de $1,13 \pm 0,18 \mathrm{~cm}$. A veia hepática demonstrou fluxo polifásico no Doppler pulsátil, com dois picos retrógrados e um pico anterógrado com velocidade de fluxo de $25,7 \pm 0,83 \mathrm{~cm} / \mathrm{s}$. A aorta abdominal tinha um diâmetro de 0,58 $\pm 0,05 \mathrm{~cm}$ e uma velocidade de fluxo de $115,17 \pm 5,32 \mathrm{~cm} / \mathrm{s}$. Os estudos morfológico e hemodinâmico das estruturas abdominais do queixada, observadas por meio das ultrassonografias modo-B e Doppler, auxiliaram na identificação do tamanho, da forma, da posição, da ecogenicidade e da ecotextura dos órgãos abdominais e na realização de inferências sobre os parâmetros de normalidade para as estruturas nas espécies.

Palavras-chave: abdome, hemodinâmica, morfologia, Tayassuidae, ultrassom

Recebido em 10 de agosto de 2020

Aceito em 14 de dezembro de 2020

*Autor para correspondência (corresponding author)

E-mail: flavioribeiro@ufpi.edu.br 


\section{INTRODUCTION}

Ultrasonography has been increasingly used in the routine diagnosis of pathological processes in wild species, especially as it is a noninvasive method and allows real-time characterization of abdominal and thoracic structures in these animals (Cruz and Freitas, 2001). A number of studies have addressed the morphological aspects of abdominal structures in wild species such as giant anteaters (Myrmecophaga tridactyla) (Lopes et al., 2015), forest foxes (Cerdocyon thous) (Silva et al., 2014), lowland pacas (Cuniculus paca) (Oliveira et al., 2003, 2007; Feliciano et al., 2014), agouti (Dasyprocta prymnolopha) (Sousa et al., 2012, 2016, 2017), peccaries (Tayassu tajacu) (Peixoto et al., 2012), coatis (Nasua nasua) (Ribeiro et al., 2013), tufted capuchin monkeys (Cebus apella) (Alves et al., 2007), cheetahs (Acinonyx jubatus) (Carstens et al., 2006), and white-tufted-ear marmosets (Callithrix jacchus) (Wagner and Kirberger, 2005).

The peccary is a wild mammal belonging to the order Artiodactyla, family Tayassuidae, and genus Tayassu. Its weight varies between 18 and $25 \mathrm{~kg}$, and its height is between 40 and $50 \mathrm{~cm}$ (Orr, 1986). Peccaries are found from the southwestern United States to Argentina living in diverse habitats (Bodmer and Sowls, 1993; Miller and Fowler, 2012), which demonstrates their great resistance and adaptability. Although some data on the ultrasonographic anatomy of the peccary have been addressed by Peixoto et al., (2012), this is the first study to acquire morphological data from hemodynamic measurements using ultrasonography in this species. This study used B-mode and Doppler ultrasonography to characterize and evaluate the abdominal structures of peccaries raised in captivity, generating data that allow inferences to be made on parameters of morphological normality, on the basis of ultrasonographic and Doppler-velocimetric anatomical criteria, as part of a collaboration for the ecological preservation of these tayassuids.

\section{MATERIALS AND METHODS}

Fifteen adult peccaries (Tayassu tajacu, Linnaeus, 1758) were used for this study: eight males and seven females, with ages varying between 1 and 2 years and weights between 15 and $18 \mathrm{~kg}$. All animals were healthy, with nutritional management characterized by the offer of commercial pig feed containing $18.0 \%$ crude protein, $3,300 \mathrm{kcal} / \mathrm{kg}$ of digestible energy, twice a day, in addition to continuous access to water. These peccaries were acquired from the Center for the Study and Preservation of Wild Animals (NEPAS) (IBAMA Registry $\mathrm{N}^{\circ}$ 02/08618), Center for Agricultural Sciences (Centro de Ciências Agrárias - CCA), Federal University of Piauí (Universidade Federal do Piauí - UFPI), Teresina, Piauí State, Brazil (502'45.7"S 4246'53.7"W).

This study was approved by the Committee on Ethics in Animal Experimentation (Comitê de Ética em Experimentação Animal CEEA/UFPI) ( $\left.N^{\circ} 013 / 15\right)$ and authorized by the System of Authorization and Information on Biodiversity (Sistema de Autorização e Informação da Biodiversidade - SISBIO) of the Brazilian Institute of Environment and Renewable Natural Resources (Instituto Brasileiro do Meio Ambiente e Recursos Naturais Renováveis - IBAMA) (N47199-1).

The animals were fasted from food for 12 hours and water for 3 hours and captured in their enclosures with hand nets. For chemical immobilization, a combination of $15 \mathrm{mg} / \mathrm{kg}$ of ketamine hydrochloride $\left(\right.$ Vetanarcol $\left.^{\circledR}\right)$ and $3 \mathrm{mg} / \mathrm{kg}$ of midazolam maleate (Dormonid $^{\circledR}$ ) was applied intramuscularly. The animals were manipulated after 15 minutes, when the onset of the anesthetic effect was verified, for a duration of 45 minutes, and no reinforcement dose was necessary to complete the ultrasonographic procedure.

The animals were positioned in dorsal decubitus, and a wide trichotomy of the abdomen was performed. The exams were carried out using MTurbo equipment (Sonosite FUJIFILM ${ }^{\circledR}$ ) coupled to a multifrequency sector transducer (P10x, from 4.0 to $8.0 \mathrm{MHz}$ ). The exam was initiated using the urinary bladder as an acoustic window and with a counterclockwise abdominal scan. The kidneys, left adrenal gland, spleen, stomach, pancreas, liver, right kidney, and right adrenal gland were inspected. The abdominal vessels and intestinal loops were inspected after this primary analysis. The analyzed morphological characteristics are described in Table. 1. 


\section{B-mode and Doppler et al.}

The aorta, in its abdominal portion (at the level of the renal artery); the renal arteries; caudal vena cava; hepatic vein; and portal vein were accessed by color and pulsed Doppler. The measurements of flow by colored Doppler measured the streamlines and direction of blood flow in the vessels. Pulsed Doppler was used to evaluate the systolic peak velocity (SPV), final diastolic velocity (FDV), and resistivity index (RI). Insonation angles smaller than $60^{\circ}$ were used to obtain the maximum Doppler signal response. The data were subjected to error normality tests (Shapiro-Wilk and Kolmogorov-
Smirnov tests), and the means were then analyzed using a paired Student's t-test to interpret the parameters, with a confidence interval of $5 \%(\mathrm{P}<0.05)$.

\section{RESULTS}

The urinary bladder was ovoid in shape and located in the abdominal and pelvic transition, presenting discrete fluctuating echogenic content. The wall was hyperechogenic, thin, smooth, and regular, with a mean thickness of $0.20 \pm 0.04 \mathrm{~cm}$ (Figure 1A).
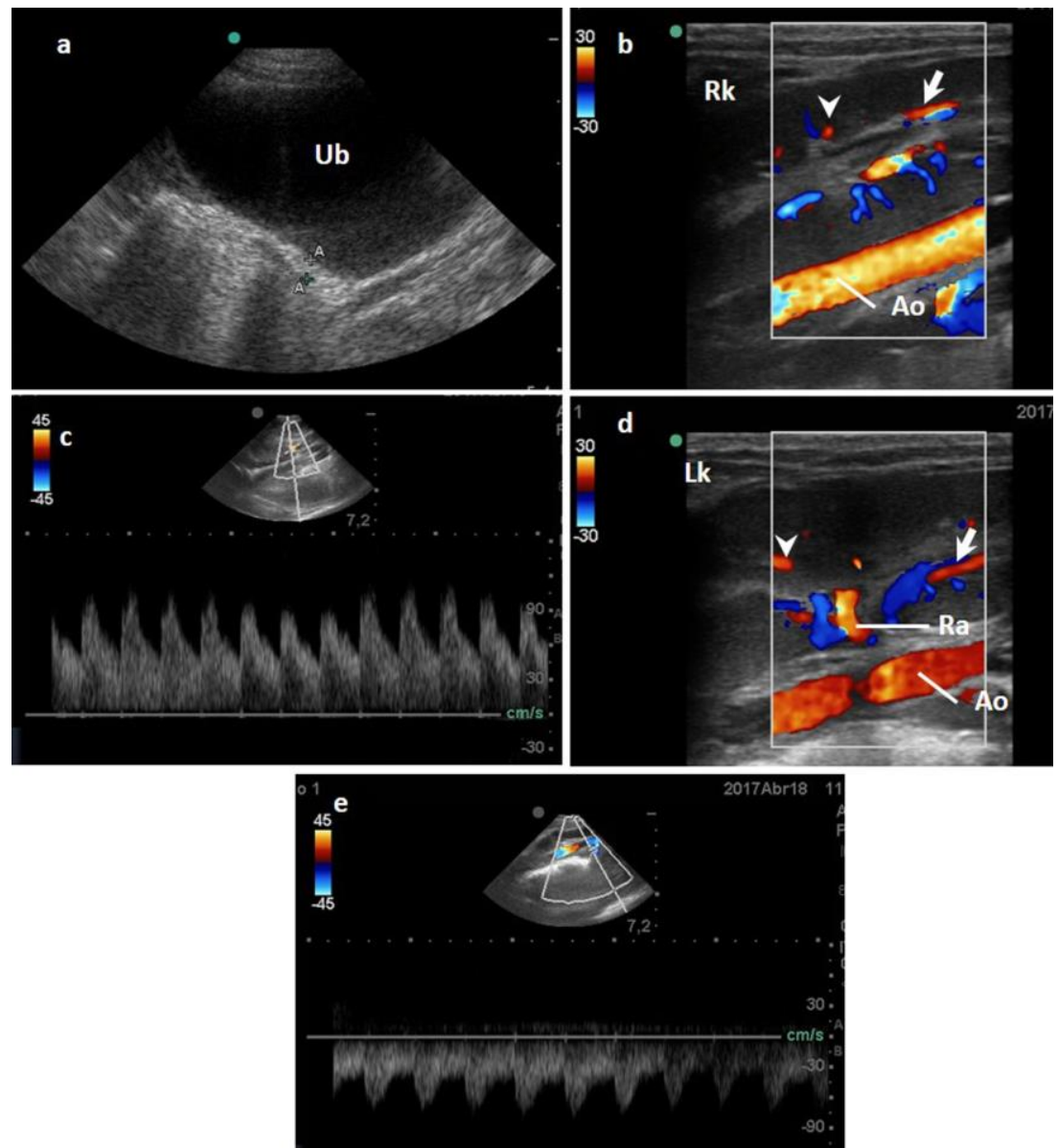

Figure 1. Ultrasound imaging in B-mode and in color and spectral Doppler of the abdominal organs of the peccary (Tayassu tajacu, Linnaeus 1758). (a) Ultrasonographic aspects of the urinary vesicle. Note the smooth and echogenic walls with a slight amount of sediment on the interior. (b) and (d) Color flow and B-mode renal morphology of the right and left kidneys, respectively, showing the usual echotexture and parenchymal echogenicity and preserved corticomedullary limit. The distal plane shows the ultrasonographic aspects of the aorta (Ao) at the level of the renal topography for adequate measurement of this vessel's diameter and the kidney/aorta ratio. Note the renal artery (Ra) arising to the aorta. (c) and (e) The pattern of flow of the renal artery and arcuate (arrow) and interlobar (arrowhead) arteries observed with color Doppler. The pulsed Doppler reveals well-defined systolic and diastolic peaks. 
The kidneys showed retroperitoneal topography, with the right kidney positioned more cranially. The splenic caudal margin appeared to coexist with the cranial pole of the left kidney. The cranial pole of the right kidney was shown to be near the liver, within the same antimere (hepatorenal fossa). A two-dimensional ultrasonographic examination of the left kidney showed a homogeneous, thin, and hypoechogenic echotexture compared to the spleen, and the right kidney showed an isoechogenic or discreetly hypoechogenic echotexture compared to the liver. The corticomedullary border was preserved and well individualized, and the pelvic recess was free of obstructive processes, dilations, and stones (Figure 1B and D).

The right and left kidneys were similar in length and diameter, and no significant difference existed between them for these variables $(\mathrm{P}>0.05)$. The kidney/aorta ratio showed mean values of $10.53 \pm 0.15 \mathrm{~cm}$ (right kidney) and $10.23 \pm 0.12 \mathrm{~cm}$ (left kidney), with no significant difference $(P>0.05)$ between these averages (Table. 2). A positive and elevated correlation was observed between the renal length and aortic diameter: $r=0.91$ (right kidney/aorta) and $r=0.97$ (left kidney/aorta) (Figure 2).
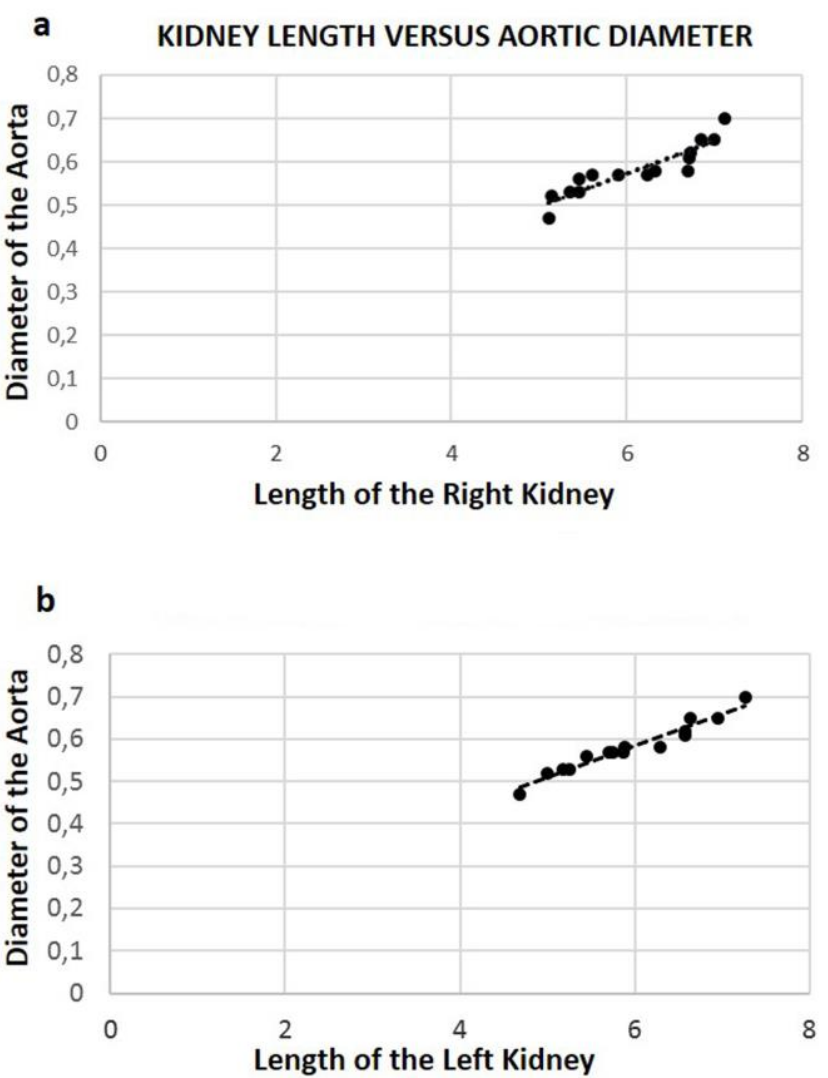

Figure 2. Correlation between the renal length and aortic diameter of the peccary (Tayassu tajacu, Linnaeus 1758). (a) Correlation between the right kidney and the diameter of the aorta. (b) Correlation between the left kidney and the diameter of the aorta.

Renal artery hemodynamic evaluation demonstrated the presence of laminar flow throughout, without the occurrence of stenosis, dilations, or hypo flow. This artery bifurcates into the renal hilum and provides the origin of the interlobular and arcuate arteries within the renal parenchyma (Figure 1B and D). Pulsed
Doppler ultrasonography of the renal artery demonstrated the presence of semi parabolic flow with a pattern of low resistance, a high systolic peak (velocities of $114.33 \pm 5.42 \mathrm{~cm} / \mathrm{s}$ in the right kidney and $116.58 \pm 5.26 \mathrm{~cm} / \mathrm{s}$ in the left kidney), a characteristic protodiastolic notch, and a continuous and full diastolic portion, which 


\section{B-mode and Doppler et al.}

decreases gradually during diastole (Figure 1C and $\mathrm{E}$, respectively). The resistivity indices for these animals showed mean values of $0.64 \pm 0.11$ (right kidney) and $0.65 \pm 0.08$ (left kidney), with no significant difference for these variables $(P>0.05)$ (Table. 2).

The abdominal aorta was observed in its abdominal path from the aortic hiatus, giving rise to the celiac trunk, cranial mesenteric artery, renal artery, and iliac arteries. No significant difference existed in the diameter over the entire path examined $(P>0.05)$. Thus, the measurement of the diameter and the Doppler-velocimetric indices were standardized at the level of the renal arteries. Laminar flow was observed with a flat and high systolic peak, a wide spectral window, and a flow pattern of high resistivity. The diameter of the abdominal aorta was $0.58 \pm 0.05 \mathrm{~cm}$, and the flow velocity measured $115.17 \pm 5.32 \mathrm{~cm} / \mathrm{s}$, with an RI measuring 0.78 (Figure $3 \mathrm{~A}$ and $\mathrm{B}$ ).
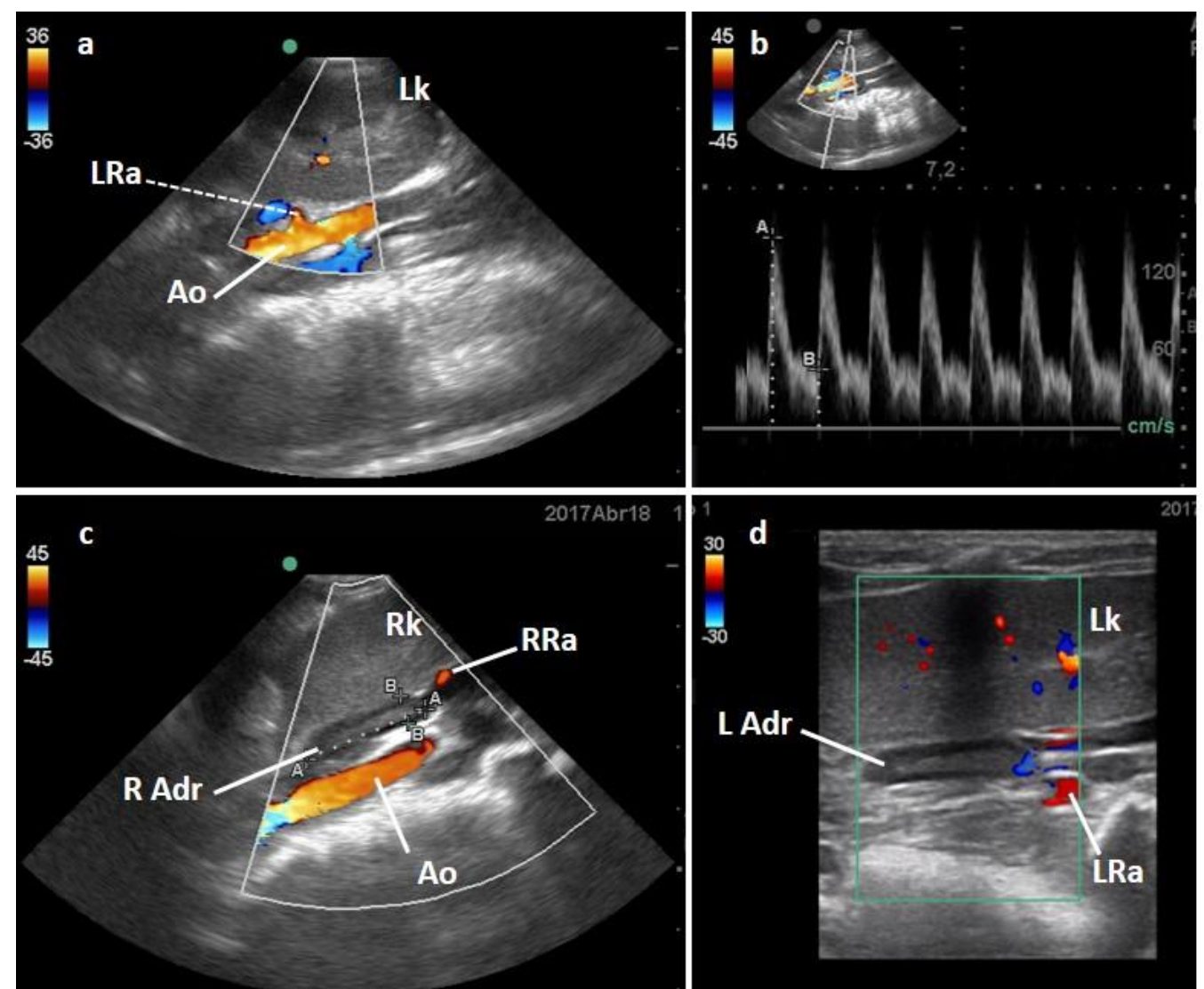

Figure 3. Ultrasound imaging in B-mode and in color and spectral Doppler of the abdominal organs of the peccary (Tayassu tajacu, Linnaeus 1758). (a) and (b) The color and pulsed characteristics of the abdominal aorta (Ao). Laminar flow was observed with a flat and high systolic peak, a wide spectral window, and flow pattern of high resistivity. The left kidney (Lk) was observed in the proximal plane and the left renal artery (LRa) was observed arising from the aorta. (c) The right adrenal gland (R Adr) is located cranially to the right renal artery (RRa) and medially to the cranial pole of the right kidney (Rk). (d) The left adrenal gland (L adr) was observed cranially to the left renal artery, ventrally to the aorta, and in varied coexistence with the cranial pole of the left kidney (Lk).

The adrenal glands were paired, bilobed, and elliptical in shape, with greater variation occurring in the right adrenal gland. They were situated ventrally to the second or third lumbar vertebrae, in the retroperitoneal space. The right adrenal gland is located cranially to the right renal artery, medially to the cranial pole of the right kidney, in close proximity to the origin of the celiac and cranial mesenteric arteries, and dorsally to the caudal vena cava. The left adrenal 
gland was seen cranially to the left renal artery, ventrally to the aorta, and in varied coexistence with the cranial pole of the left kidney, depending on the location of this organ. The right adrenal gland showed a variation in length between 1.55 and $2.66 \mathrm{~cm}(1.93 \pm 0.34 \mathrm{~cm})$ and a diameter ranging from 0.36 to $1.05 \mathrm{~cm}$ $(0.56 \pm 0.16 \mathrm{~cm})$. The left adrenal gland had a length between 1.25 and $2.84 \mathrm{~cm}(1.85 \pm 0.42 \mathrm{~cm})$ and a diameter between 0.36 and $0.77 \mathrm{~cm}$ $(0.52 \pm 0.11 \mathrm{~cm})$, with no difference between the means for the variables studied (Figure $3 \mathrm{C}$ and D) $(P>0.05)$.

The pancreas had a regular and defined contour and was distinguishable in its topography from other structures. The right lobe was positioned dorsomedially to the descending duodenum, ventrally to the right kidney, ventrolaterally to the portal vein, and in close relation with the pyloric portion of the stomach. Its echotexture was homogeneous and hyperechogenic. The pancreatic duct was distinguished within this organ by the echogenic characteristic of its walls. Discernment of precise segments of the left lobe was well defined with similar echotexture of the right pancreas. The thickness of the pancreas was $0.79 \pm 0.23 \mathrm{~cm}$ (right lobe) and $0.87 \pm 0.21 \mathrm{~cm}$ (left lobe). The pancreatic duct measured $0.17 \pm 0.05 \mathrm{~cm}$ (right lobe) and $0.14 \pm 0.02 \mathrm{~cm}$ (left lobe) (Figure 4A and B).

The stomach contained gases and was positioned caudally to the liver from a longitudinal approach. The stomach wall was $0.18 \pm 0.05 \mathrm{~cm}$ in thickness, echogenic with a homogeneous echotexture, and positioned to the left of the spleen and the right of the proximal duodenum and transverse colon (Figure 4C). The proximal duodenum had a thickness of $0.4 \pm 0.13 \mathrm{~cm}$ and was positioned laterally to the right wall. The other segments of the duodenum and intestinal loops could not be adequately identified due to the amount of gases present in the loops during the examination.
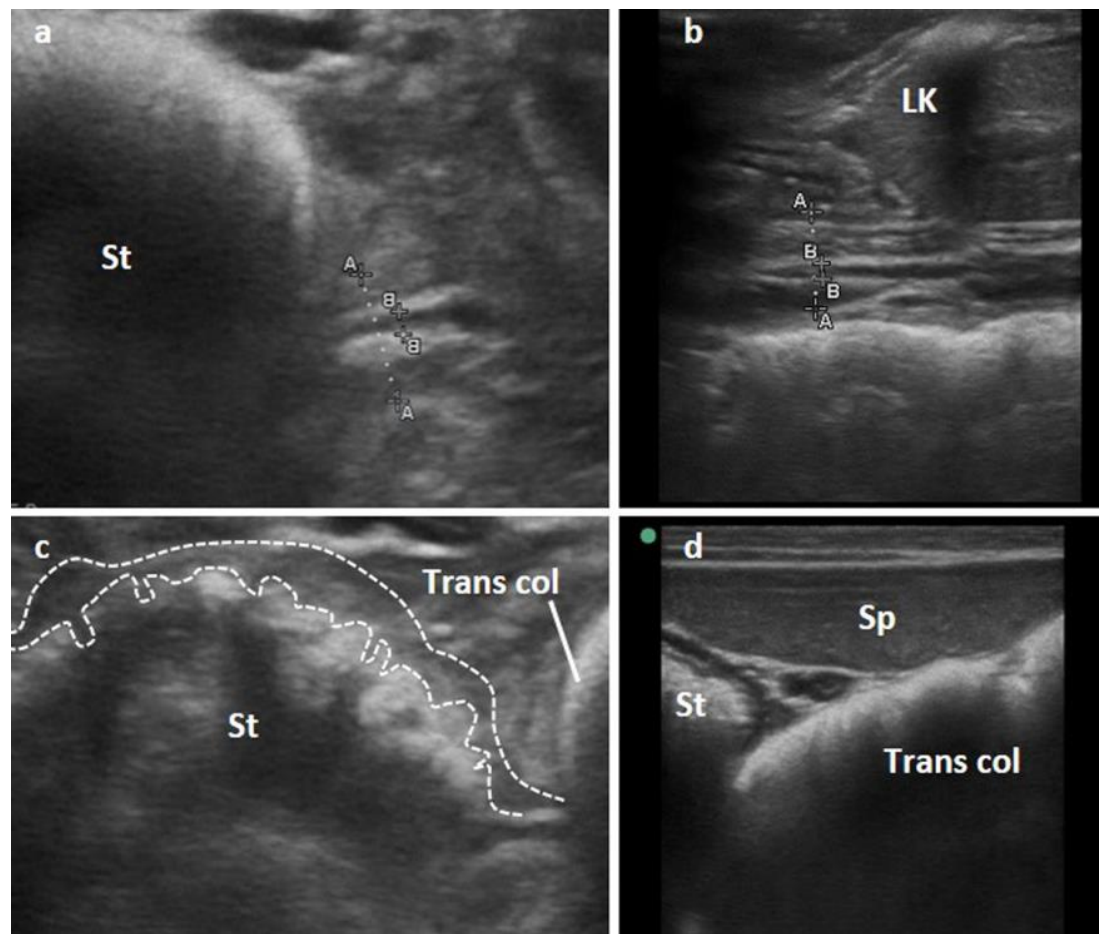

Figure 4. Ultrasound imaging in B-mode of the abdominal organs of the peccary (Tayassu tajacu, Linnaeus 1758). (a) and (b) Right and left lobes of the pancreas, respectively. Its echotexture was homogeneous and hyperechogenic. The pancreatic duct was distinguished within this organ by the echogenic characteristic of its walls. (c) The stomach, echogenic and with homogeneous echotexture, and its closed relationship with the transverse colon. (d) The spleen with filiform shape, with pointed poles, maintaining a syntopic relation with the greater curvature of the stomach. 


\section{B-mode and Doppler et al.}

The spleen had a filiform shape, with pointed poles and a diameter of $1.13 \pm 0.18 \mathrm{~cm}$, maintaining a syntopic relation with the greater curvature of the stomach and the cranial pole of the left kidney. Its echotexture appeared to be fine and homogeneous throughout its length, being more echogenic than the cortical of the left kidney (Figure 4D). The liver of the peccary occupies the cranial space of the abdominal cavity and is in direct contact with the diaphragm (Figure 5A). The hepatic lobulation cannot be adequately described by ultrasonography because the echotexture and similar acoustic impedances between lobes prevent proper individualization in normal animals (without the presence of peritoneal effusion).

However, this organ presents impressions of the adjacent structures, which can be adequately described, relating centrally to the stomach, with the right kidney (hepatorenal fossa) and duodenum in the most cranial portion. The echotexture of the liver is thin and homogeneous, isoechogenic in relation to the renal cortical parenchyma, and hypoechoic in relation to the spleen. Although approaches were attempted on the sagittal and subcostal planes of both antimeres, the gallbladder was not visible in any of the studied animals.
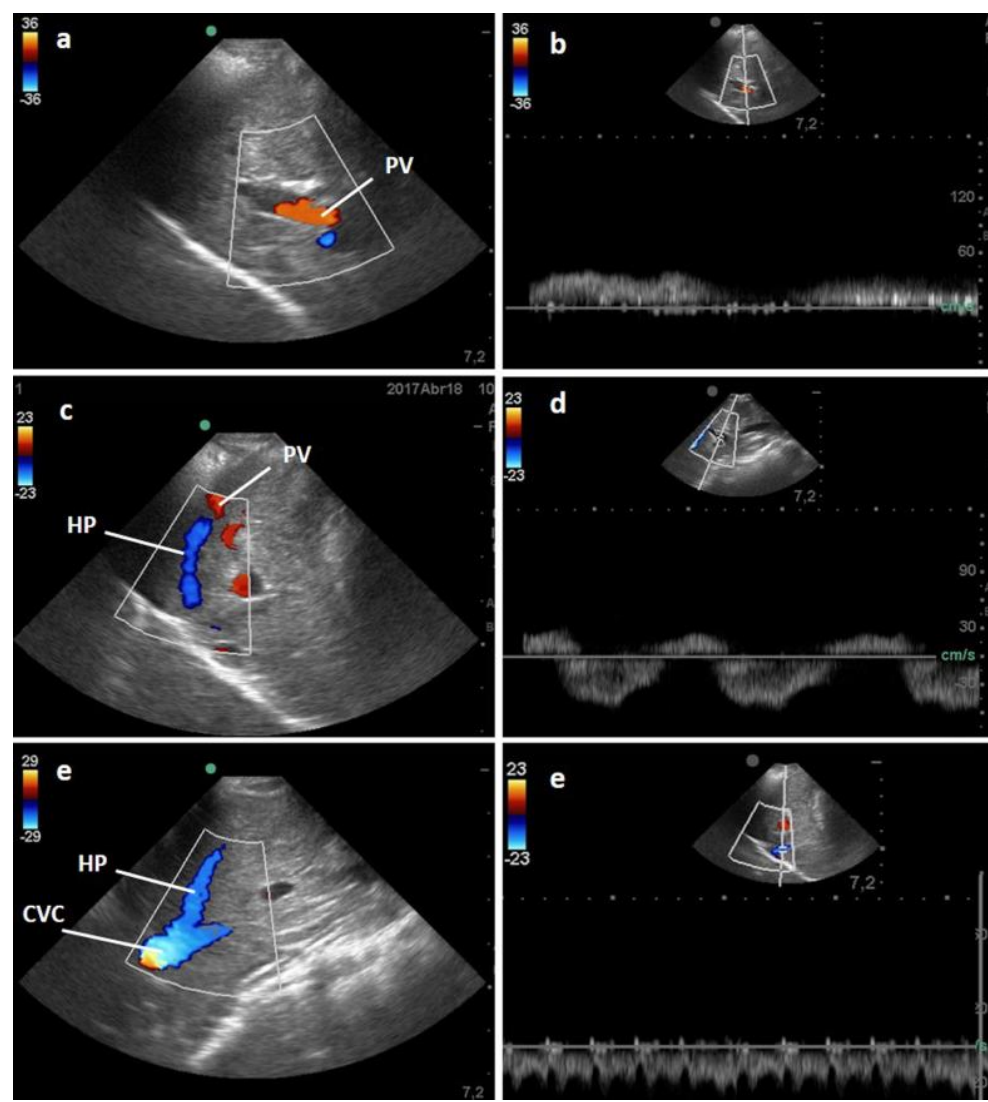

Figure 5. Ultrasound imaging in B-mode and in color and spectral Doppler of the liver of the peccary (Tayassu tajacu, Linnaeus 1758). (a)-(c) Using color Doppler, the portal flow showed a color map with a red (hepatopetal) signal, while the hepatic veins showed a blue (hepatofugal) signal. Note the laminar flow in both vessels. The portal vein showed a relatively broad and linear pulse discretely influenced by the respiratory phase. (d) The pulsed Doppler in the hepatic vein showed a polyphasic flow, with two retrograde peaks and one anterograde peak. (e)-(f) The profile wave of the caudal vena cava, laminar and with two evident anterograde peaks.

The portal vein was distinguished in the ultrasound examination by the echogenic pattern of its walls compared to the hepatic veins. Using color Doppler, the portal flow showed a color map with a red (hepatopetal) signal, while the hepatic veins showed a blue (hepatofugal) signal 
(Figure 5A and C). The flows were laminar in both vessels. When analyzed with pulsed Doppler, the portal vein showed a relatively broad and linear pulse that was discretely influenced by the respiratory phase, with flow velocity measured at $21.17 \pm 1.32 \mathrm{~cm}$ and an RI of $0.37 \pm 0.09$ (Figure 5B).

The color Doppler in the hepatic vein showed laminar flow (Figure 5C). Pulsed Doppler in this vein showed a polyphasic flow, with two retrograde peaks and one anterograde peak with a velocity of $25.7 \pm 0.83 \mathrm{~cm} / \mathrm{s}$; this last peak reflected the influence of the cardiac cycle (Figure 5D). The caudal vena cava receives the hepatic veins and could be seen in the distal plane of the liver, accessed from the left subcostal region. The caudal vena cava had laminar flow, with a flow velocity of $46.47 \pm 2.34 \mathrm{~cm} / \mathrm{s}$ and an RI of $0.42 \pm 0.06$ (Figure $5 \mathrm{E}$ and $\mathrm{F})$.

\section{DISCUSSION}

The ultrasound evaluations of the abdominal structures of the studied peccaries were performed in planes cut along the longitudinal, transverse, and dorsal axes (Barberet et al., 2008). Although the animals were fasted from food for 12 hours and water for 3 hours, the difficulty of emptying the gastrointestinal tract of wild animals has been recognized (Sousa et al., 2012). This difficulty is a limiting factor in the adequate preparation for ultrasonographic examinations, with the main implication being the amount of gas found in the intestinal loops, as observed in this study. However, Garcia and Froes (2014) report that no significant changes were observed in the ultrasound patterns of abdominal structures of animals with and without fasting.

Chemical immobilization is part of the ultrasonographic protocol for wild species, especially in order to minimize immobilization stress and ensure adequate manipulation safety for the animal and the examiner (Batista et al., 2009). The anesthetic protocol used in this study produced adequate sedation without hemodynamic compromise, which would alter the flow measurements taken (all animals were monitored for cardiovascular changes using an electrocardiogram and blood pressure measurements). This anesthetic protocol was used with great success in the peccary by Pessoa et al., (2014) to collect adipose tissue, by Argôlo Neto et al., (2016) to collect bone marrow, and by Bezerra et al., (2014) in establishing a preclinical model of renal injury from renal artery clamping. Batista et al., (2009) reported that chemical tranquilization in the peccary significantly reduces heart rate, rectal temperature, biochemical parameters, and stress indicators, making it easier to manipulate the animal.

The urinary vesicle presented similar shape, location, and syntropy to those observed in other wild and domestic animals, such as cheetahs (Acinonyx jubatus) (Carstens et al., 2006), forest foxes (Cerdocyon thous) (Silva et al., 2014), coatis (Nasua nasua) (Ribeiro et al., 2013), and lowland pacas (Cuniculus paca) (Oliveira et al., 2003, 2007; Feliciano et al., 2014). In the whitetufted-ear marmoset (Callithrix jacchus), the urinary vesicle is multilobulated (Wagner and Kirberger, 2005), differing from the ovoid shape found in the peccary in the present study. The urinary vesicle of the animals studied presented a thickness of $0.20 \pm 0.04 \mathrm{~cm}$, corroborating the descriptions made for the same species by Peixoto et al., (2012) $(0.20 \pm 0.08 \mathrm{~cm})$. The lower standard deviation observed in the present study probably occurred because of the larger number of samples evaluated and the use of a probe that allowed greater measurement precision. In addition, similar values were found by Alves et al., (2007) in tufted capuchin monkeys (Cebus apella).

The kidneys of the evaluated peccary presented an ultrasonographic appearance similar to that described for healthy dogs of similar size (Hart et $a l$. , 2013). Regarding renal morphometry, the measurements of this study were close to the values established by Sampaio and Araújo (2002) for dogs of unspecified breed with weights between 10.1 and $20 \mathrm{~kg}$. The preserved corticomedullary limit encountered in the peccaries was also observed by Silva et al., (2014) in forest foxes (Cerdocyon thous) and by Feliciano et al., (2014) in lowland pacas (Cuniculus paca). Renal size is an important parameter in evaluating renal disease with an acute or chronic outcome. In dogs, renal size is naturally difficult to measure using an ultrasound, principally due to the great variation in animal size and breed differentiation (Barberet 
et al., 2008). Mareschal et al., (2007) established a standard of renal size normality (kidney/aorta ratio) between 5.5 and 9.1 when the relation between the kidney length and luminal diameter of the aorta is measured. The kidney/aorta ratio in the peccaries studied $(10.53 \pm 0.15$ for the right kidney and $10.23 \pm 0.12$ for the left) can be elucidative when determining the size and function of kidneys because of the small variation in the peccary body score.

Renal evaluation using color Doppler showed laminar flow and absence of stenosis, dilations, or hypoflows. Similarly, pulsed Doppler $(114.33 \pm 5.42 \mathrm{~cm} / \mathrm{s}$ in the right kidney and $116.58 \pm 5.26 \mathrm{~cm} / \mathrm{s}$ in the left kidney) showed values higher than those observed in dogs by Melo et al., (2006). This divergence is probably found in the hemodynamic response characteristic of the vascular wall, as occurs in humans (Viazzi et al., 2014), where velocity variations that reach $100 \mathrm{~cm} / \mathrm{s}$ are considered normal in the presence of laminar flow, spectral wave morphology, and preserved resistivity indices. In fact, in the present study, pulsed flow patterns were similar to those described in the literature, and resistivity indices indicated a low resistivity flow pattern $(0.64 \pm 0.11$ in the right renal artery and $0.65 \pm 0.08$ in the left renal artery). In wild felines (Acinonyx jubatus), Carstens et al., (2006) found an index with an average value (0.58) similar to that observed in the peccary.

As with domestic animals (dogs and cats), where ultrasonographic abdominal study is well established, evaluations of the adrenal gland show high variation and standard deviations. These results are caused by variation in size and breeds (Mareschal et al., 2007). Wild species are devoid of measurement values for the adrenal gland (Alves et al., 2007). In dogs, the threshold value suggesting an adrenal increase is $0.74 \mathrm{~cm}$ (Barthez et al., 1995). Soulsby et al., (2015) stratified maximum values according to the size of the animals and based on the caudal adrenal pole thickness in the sagittal plane: canines weighing $<10 \mathrm{~kg}(0.54 \mathrm{~cm})$, between 10 and $30 \mathrm{~kg}$ $(0.68 \mathrm{~cm})$, and $>30 \mathrm{~kg}(0.80 \mathrm{~cm})$. For the peccaries examined in the present study, the average values of $0.56 \pm 0.16 \mathrm{~cm}$ and $0.52 \pm 0.11 \mathrm{~cm}$ were obtained for the right and left adrenal glands, respectively. Thus, the peccaries in this experiment fit into the weight range of $<10 \mathrm{~kg}$, although the right adrenal gland had a slightly elevated mean value.

The spleen of the tayassuids had a thin homogeneous echotexture, similar to that observed by Silva et al., (2014) in forest foxes (Cerdocyon thous) and by Feliciano et al., (2014) in lowland pacas (Cuniculus paca). The echogenicity of the spleen was higher than that of the left renal cortical, a fact also observed in coatis (Nasua nasua) by Ribeiro et al., (2013) and in forest foxes (Cerdocyon thous) by Silva et al., (2014) The diameter of this organ $(1.13 \pm 0.18 \mathrm{~cm})$ established in this study was lower than that reported by Peixoto et al., (2012) for the same species. However, our research used a larger number of animals, of both sexes, and showed lower standard deviation when compared to the data reported by Peixoto et al., 2012.

The liver occupies the cranial space of the abdominal cavity and shows a homogeneous echotexture and the absence of a gallbladder. The absence of the gallbladder had previously been reported in anatomical studies by Sowls (1974). A hepatic parenchyma with homogeneous contrast characteristics was also described by Ryu et al., (2009) in computed tomography studies. In the peccary, flow velocities of the hepatic vein $(25.7 \pm 0.83 \mathrm{~cm} / \mathrm{s})$ and caudal vena cava $(46.47 \pm 2.34 \mathrm{~cm} / \mathrm{s})$ were observed to be greater than the velocities established by Carstens et al., (2006) in cheetahs $(21.23 \pm 0.41 \mathrm{~cm} / \mathrm{s}$ and $33.8 \pm 19.8 \mathrm{~cm} / \mathrm{s}$, respectively) for the same veins. The hepatic vein flow pattern exhibited by pulsed Doppler was characterized by a peak above the baseline and two peaks below it, showing the influence of the cardiac cycle on this blood vessel. Corroborating our results, Huang et al., (2004) also identified biphasic flow of the hepatic vein correlated with breathing or pressure changes in the right atrium. Bogin et al., (2005) reported that hepatic and portal vein flow velocities are important in evaluating occlusive vascular diseases in humans, mainly with inverted portal vein flow and reduced monophasic hepatic flow velocity.

Barberet et al., (2008) quantified the detection of pancreatic ultrasound images and verified that the right pancreatic lobe, pancreatic body, and left pancreatic lobe had frequencies of $56 \%$, $60 \%$, and $87 \%$, respectively, in 100 canine 
patients. In the peccary, only the right lobe was visualized, located dorsomedially to the descending duodenum, ventrally to the right kidney, and ventrolaterally to the portal vein. This characteristic was also described by SantisPrada and Duti Neto (1978) in swine. These authors reported a pancreas of small size and annular appearance, completely enfolding the intestine. Although a detailed anatomical description of this organ has been made, the relation of its proximity to the proximal duodenum and its small dimensions may have made it difficult to fully visualize the pancreas using ultrasonographic examination, making its echogenicity diffuse, marginally delineated, and difficult to distinguish.

The ultrasound characteristics of the stomach of Tayassu tajacu are unique. According to Cavalcante-Filho et al., (1998), these animals have a pluricavitary stomach formed by two blind sacs, one cranioventral and one caudodorsal; one gastric pouch; and one compartment located in the right antimere. The walls of the stomach $(0.18 \pm 0.05 \mathrm{~cm})$ and duodenum $(0.4 \pm 0.13 \mathrm{~cm})$ of the peccary are thicker than those of the stomach $(0.10 \pm 0.01 \mathrm{~cm})$ and duodenum $(0.19 \pm 0.04 \mathrm{~cm})$ of rabbits (Banzato et al., 2015) and forest foxes $(0.39 \pm 0.05 \mathrm{~cm})($ Silva et al., 2014).

Kamikawa and Bombonato (2007) described the mean diameter of the abdominal aorta at $0.74 \mathrm{~cm}$, whereas for the peccary, these values were $0.58 \pm 0.05 \mathrm{~cm}$. Nevertheless, this characteristic does not appear to have produced hemodynamic interference in the flow values of this artery. Carvalho et al., (2008) described mean aortic flow velocities of $95.49 \pm 35.43 \mathrm{~cm} / \mathrm{s}$ for domestic dogs, and in this study, the aortic flow for the peccary was $115.17 \pm 5.32 \mathrm{~cm} / \mathrm{s}$, which is slightly higher than the flow found in dogs of equal size.

\section{CONCLUSIONS}

The morphological and hemodynamic study of the abdominal structures of the peccary, by means of B-mode and Doppler ultrasonography, aided in identifying the size, shape, position, echogenicity, and echotexture of abdominal organs. Together with Doppler-velocimetric index measurement, this study allows the inference of normal parameters for these structures in this species.

\section{REFERENCES}

ALVES, F.R.; COSTA, F.B.; AROUCHE, M.M.S. et al. Avaliação ultra-sonográfica do sistema urinário, figado e útero do macacoprego, Cebus apella. Pesq. Vet. Bras., v.27, p.377-382, 2007.

ARGÔLO NETO, N.M.A.; FEITOSA, M.L.T.; SOUSA, S.S. et al. Isolation, expansion, differentiation and growth kinetics essay in mesenchymal stem cells culture from the bone marrow of collared peccaries (Tayassu tajacu). Acta Sci. Vet., v.44, p.1-11, 2016.

BANZATO, T.; BELLINI, L.; CONTIERO, B., SELLERI, P.; ZOTTI, A. Abdominal ultrasound features and reference values in 21 healthy rabbits. Vet. Rec., v.176, p.101, 2015.

BARBERET, V.; SCHERERS, E.; RADEMACHER, N. et al. Quantification of the effect of various patient and image factors on ultrasonographic detection of select canine abdominal organs. Vet. Radiol. Ultrasound, v.49, p.273-276, 2008.

BARTHEZ, P.Y.; NYLAND, T.G.; FELDMAN, E.C. Ultrasonographic evaluation of the adrenal glands in dogs. Vet. Radiol. Ultrasound, v.207, p.1180-1183, 1995.

BATISTA, J.S.; BEZERRA, F.S.B.; AGRA, E.G.D. et al. Efeitos da contenção física e química sobre os parâmetros indicadores de estresse em catetos (Tayassu tajacu). Acta Vet. Bras., v.3, p.92-97, 2009.

BEZERRA, D.O.; FEITOSA, M.L.; ALMEIDA, H.M. et al. Collared pecary (Tayassu tajacu) as a new model of renal ischemic injury induced by clamping the renal artery. Acta Cir. Bras., v.29, p.560-572, 2014.

BODMER, R.E.; SOWLS, L.K. The collared Peccary (Tayassu tajacu). In: OLIVER, W.L.R. (Ed.). Pigs, peccaries and hippos: status survey and conservation action plan. Switzerland: IUCN, 1993. p.7-13.

BOGIN, V.; MARCOS, A.; SHAW-STIFFEL, T. Budd-Chiari syndrome: in evolution. Eur. J. Gastroenterol. Hepatol., v.17, p.33-35, 2005. 
CARSTENS, A.; KIRBERGER, R.M.; SPOTSWOOD, T.; WAGNER, W.M.; GRIMBEEK, R.J. Ultrasonography of the liver, spleen, and urinary tract of the cheetah (Acinonyx jubatus). Vet. Radiol. Ultrasound, v.47, p.376383, 2006.

CARVALHO, C.F.; CHAMMAS, M.C.; STERMAN, F.D.A., NESTOR, B., GUIDO, C.G. Ultra-sonografia dúplex-Doppler na avaliação morfológica e hemodinâ $\neg$ mica das artérias aorta e mesentérica cranial em cães. Braz. J. Vet. Res. Anim. Sci., v.45, p.24-31, 2008.

CAVALCANTE-FILHO, M.; MIGLINO, M.; MACHADO, G.; BEVILACQUA, E.; NEVES, W.C. Comparative study of the morphology of the stomach of white lipped peccary (Tayassu pecari) and of the collared peccary (Tayassu tajacu). Braz. J. Vet. Anim. Sci., v.35, p.20-24, 1998.

CRUZ, J.; FREITAS, V. A ultra-sonografia em tempo real na reprodução de caprinos. Cienc. Anim., v.11, p.45-53, 2001.

FELICIANO, R.; ANTONIO, M.; BARROS, F.F. et al. Conventional and doppler abdominal ultrasonography in pacas (Cuniculus paca). Acta Sci.Vet., v.42, p.1-6, 2014.

GARCIA, D.A.; FROES, T.R. Importance of fasting in preparing dogs for abdominal ultrasound examination of specific organs. $J$. Small Anim. Pract., v.55, p.630-634, 2014.

HART, D.V.; WINTER, M.D.; CONWAY, J.; BERRY, C.R. Ultrasound appearance of the outer medulla in dogs without renal dysfunction. Vet. Radiol. Ultrasound, v.54, p.652-658, 2013.

HUANG, T.L.; CHEN, T.Y.; TSANG, L.L. et al. Hepatic venous stenosis in partial liver graft transplantation detected by color Doppler ultrasound before and after radiological interventional management. Transplant Proc., v.36, p.2342-2343, 2004.

KAMIKAWA, L.; BOMBONATO, P.P. Ultrasonografia da aorta abdominal e de seus ramos em cães. Ciênc. Rural, v.37, p.412-417, 2007.

LOPES, É.R.; MORGADO, T.O.; MEIRELES, Y.S. et al. Ultrassonografia abdominal de tamanduás-bandeira (Myrmecophaga tridactyla Linnaeus, 1758) mantidos em cativeiro. Pesq. Vet. Bras., v.35, p.919-924, 2015.
MARESCHAL, A.; D'ANJOU, M.A.; MOREAU, M.; ALEXANDER K, BEAUREGARD G. Ultrasonographic measurement of kidney-to-aorta ratio as a method of estimating renal size in dogs. Vet. Radiol. Ultrasound, v.48, p.434-438, 2007.

MELO, M.B.; VEADO, J.C.C.; SILVA, E.F.; MOREIRA, S.M.; PASSOS, L.M.F. Dopplerfluxometria das artérias renais: valores normais das velocidades sistólica e diastólica e do índice resistivo nas artérias renais principais. Arq. Bras. Med. Vet. Zootec., v.58, p.691-693, 2006.

MILLER, R.E.; FOWLER, M.E. (Ed.). Zoo \& wild animal medicine. Philadelphia: W. B. Saunders, 2012. 512p.

OLIVEIRA, F.S.; MACHADO, M.R.F.; CANOLA, J.C. Real time B-mode ultrasound in pacas pregnancy (Agouti paca, Linnaeus, 1766). Braz. J. Vet. Res. Anim. Sci., v.40, p.73-78, 2003.

OLIVEIRA, F.S.; MACHADO, M.R.F.; CANOLA, J.C. Uniparidade em pacas criadas em cativeiro (Agouti paca, Linnaeus, 1766). Arq. Bras. Med. Vet. Zootec., v.59, p.387-389, 2007.

ORR, R.T. (Ed.). Biologia dos vertebrados. San Francisco: Academy of Sciences, 1986. 518p.

PEIXOTO, G.C.; OLIVEIRA, I.R.; ALVES, N.D.; OLIVEIRA, M.F.; SILVA, A.R. Abdominal exploration in captive collared peccaries (Tayassu tajacu) by ultrasonography. Anat. Histol. Embryol., v.41, p.256-261, 2012.

PESSOA, G.T.; FEITOSA, M.L.T.; ARGÔLO NETO, N.M. et al. Isolation, culture and differentiation potential of collared peccary (Tayassu tajacu) adipose-derived stem cells. Acta Sci. Vet., V.42, p.1-10, 2014.

RIBEIRO, R.G.; COSTA, A.P.; BRAGATO, N. Normal sonographic anatomy of the abdomen of coatis (Nasua nasua Linnaeus 1766). BMC Vet. Res., v.9, p.124, 2013.

RYU, J.M.; KIM, D.H.; LEE, M.Y. et al. Imaging evaluation of the liver using multidetector row computed tomography in micropigs as potential living liver donors. J. Vet. Sci., v.10, p.93-98, 2009.

SAMPAIO, K.M.O.R.; ARAUJO, R. Ultrasonografia de características lineares e estimativas do volume de rins de cães. Arq. Bras. Med. Vet. Zootec., v.54, p.248-254, 2002. 
SANTIS-PRADA, I.L.; DUTI NETO, J.P. Pâncreas anular em suíno. Rev. Facul. Med. Vet. Zootec. Univ., v.15, p.23-30, 1978.

SILVA, A.S.L.; FELICIANO, M.A.R.; MOTHEO, T.F. et al. Mode B ultrasonography and abdominal Doppler in crab-eating-foxes (Cerdocyon thous). Pesq. Vet. Bras., v.34, p.2328, 2014.

SOULSBY, S.N.; HOLLAND, M.; HUDSON, J.A.; BEHREND, E.M. Ultrasonographic evaluation of adrenal gland size compared to body weight in normal dogs. Vet. Radiol. Ultrasound, v.56, p.317-326, 2015.

SOUSA, F.C.; PESSOA, G.T.; MOURA, L.S. Doppler ultrasound of the placenta and maternal and fetal vessels during normal gestation in captive agoutis (Dasyprocta prymnolopha, Wagler, 1831). Theriogenology, v.86, p.19211930, 2016.

SOUSA, F.C.A.; ALVES, F.R.; FORTES, E.A.M. et al. Pregnancy in hystricomorpha: gestational age and embryonic-fetal development of agouti (Dasyprocta prymnolopha, Wagler 1831) estimated by ultrasonography. Theriogenology, v.78, p.1278-1285, 2012.
SOUSA, F.C.A.; PESSOA, G.T.; MOURA, L.S. et al. Organogenesis and foetal haemodynamics during the normal gestation of healthy blackrumped agoutis (Dasyprocta prymnolopha, Wagler, 1831) bred in captivity. Reprod. Domest. Anim., v.52, p.60-66, 2017.

SOWLS, L.K. Social behavior of the collared peccary, Dicotyles tajacu, (L). In: GEIST, V.; WALTHER, F. (Eds.). The behavior of ungulates and its relation to management. Switzerland: IUCN MORGES, 1974. p.144-165.

VIAZZI, F.; LEONCINI, G.; DERCHI, L.E.; PONTREMOLI, R. Ultrasound Doppler renal resistive index: a useful tool for the management of the hypertensive patient. J. Hypertens., v.32, p.149-153, 2014.

WAGNER, W.M.; KIRBERGER, R.M. Transcutaneous ultrasonography of the abdomen in the normal common marmoset (Callithrix jacchus). Vet. Radiol. Ultrasound, v.46, p.251258, 2005. 